\title{
Histomorphology of the porcine oviduct
}

\author{
Asuman ÖZEN, Tuğrul ERTUĞRUL, Alev Gürol BAYRAKTAROĞLU, Belma ALABAY, \\ Ahmet CEYLAN
}

\author{
Department of Histology-Embryology, Faculty of Veterinary Medicine, University of Ankara, Ankara, Turkey.
}

\begin{abstract}
Summary: The present study was aimed at the light and electron microscopic examination of the epithelium of the porcine oviduct, determination of the histochemical structure of the mucus secreted by epithelial cells, and demonstration of the localisation and distribution of endothelial nitric oxide synthase (eNOS) activity during the different stages of the oestrous cycle. The oviducts of 5 healthy adult sows constituted the material of the study. Histochemically, it was observed that, increased glycosaminoglycan (GAG) secretion during the oestrus phase, was in particular stored in the crypts of the isthmus. Electron microscopic examination revealed that, the increased amount of secretory material, which accumulated in secretory cells during the oestrus phase, was stored in two different types of secretory granules. Immunohistochemically, it was ascertained that eNOS was not expressed in either the ampulla or the fimbria during the oestrus and luteal phases, but was expressed in the isthmus only during the oestrus phase.

Key words: eNOS, histochemistry, oviduct, pig.
\end{abstract}

\section{Domuzlarda oviduktun histomorfolojisi}

Özet: $\mathrm{Bu}$ çalışma; domuzlarda ovidukt epitelinin yapısını, 1şık ve elektron mikroskobik olarak incelemek, epitel hücreleri tarafından salgılanan mukus içeriğinin histokimyasal yapısını ortaya koymak ve östrus siklusunun farklı dönemlerindeki endotelyal nitrik oksit sentaz (eNOS) aktivitesinin, lokalizasyonu ve dağılımını belirlemek amacıyla yapıldı. Çalışmada 5 adet sağlıklı, erişkin dişi domuzdan alınan ovidukt, materyal olarak kullanıldı. Histokimyasal olarak; östral dönemde artan glikozaminoglikan (GAG) salgısının, özellikle istmusdaki kriptlerde depolandığı görüldü. Elektron mikroskobik olarak; östral dönemde sekretorik hücrelerin sitoplazmalarında artan salg1 materyalinin, iki tip salg1 granülünde toplandığı belirlendi. İmmunohistokimyasal olarak; hem östral hem de luteal dönemde ampulla ve fimbriyada eNOS ekspresyonu görülmez iken, istmusda ise yalnızca östral dönemde eNOS ekspresyonu saptanmıştır.

Anahtar sözcükler: Domuz, eNOS, histokimya, ovidukt.

\section{Introduction}

In mammals, the oviduct is an organ of the female reproductive system, where oocyte maturation, spermatozoon capacitation and early embryonic development take place. The epithelium of the oviduct plays an important role in these functions $(7,11)$.

The oviduct epithelium is composed of two different types of cells, namely, ciliated and secretory cells $(1,2,19)$. Secretory cells synthesize and secrete specific proteins, glycoproteins and GAGs. The secretion of secretory cells enables the motility and capacitation of the spermatozoon in the oviduct, and aids in the nutrition of both the embryo and the oocyte II, during their passage through the oviduct, and is also used a source of energy during early embryonic cleavage $(11,13,15,22)$. Moreover, secretory cells synthesize specific proteins involved in early embryonic development and fertilization. Once synthesized, the secretory material is stored in epithelial cells until secreted into the lumen of the oviduct. In the preovulatory period, the mucus content of the oviduct contains various mucopolysaccharides, which are capable of retaining spermatozoa, as well as special glycoproteins specific to the oviduct $(9,11,17)$. In contrast to their localisation in the utero-tubal junction and isthmic reservoir in cattle, in sows, spermatozoa are located in the deeply situated narrow crypts of the oviduct $(11,18)$. It is reported that the number of ciliated cells involved in the transport of the oocyte II and zygote to the uterus is greater in the fimbrial region, compared to the ampulla and isthmus (1). In the follicular phase of the oestrous cycle, ciliated cells predominate in the fimbria and ampulla. In the luteal phase, the number and height of ciliated cells decrease markedly $(2,19,20)$.

Literature reports are available, which suggest the presence of a third type of cells, referred to as "basal" or "reserve" cells, in the epithelium of the mammalian oviduct, apart from the above mentioned two types of cells. These basal cells, which are situated basally to the lamina epithelialis, are small, spherical cells, which contain a heterochromatic nucleus. Due to their similarity 
to leukocytes and lymphocytes, from time to time, basal cells have been assessed as leukocyte- or lymphocytelike cells in humans, primates, cows, sheep, pigs and rabbits, and in some cases, even as stem cells of ciliated or secretory cells $(4,14,15,16)$.

Sows are polyoestrous animals that may enter puberty as early as 7 months of age. In sows, the oestrous cycle lasts 21 days, whilst the oestrus phase lasts 48 hours. Thirty-six hours after the onset of oestrus, ovulation occurs. The ovaries of an adult sow are surrounded entirely by the bursa ovarica. Owing to the numerous follicles and the corpus luteum they bear, the ovaries resemble a mulberry in appearance (6). The mature follicle, which is of a pinkish colour resembling that of seashells, displays a network of fine capillaries on its surface. The diameter of a mature follicle ranges between $0.8-1 \mathrm{~cm}$, whilst the diameter of a corpus luteum ranges between $1-1.3 \mathrm{~cm}(6)$.

Alcian blue $(\mathrm{Ab})$ is capable of staining sulphated (GAGs), excluding hyaluronic acid, at varying $\mathrm{pH}$ levels. Staining with periodic acid-Schiff (PAS) and Ab has shown that the amount of GAGs, used for the nutrition and protection of the spermatozoon until ovulation, increases during the prooestrus and oestrus phases. GAGs have also been identified by immunohistochemical methods, and it has been demonstrated that GAG content reaches its peak level in late prooestrus and oestrus. Ultrastructurally, it has been ascertained that, secretory cells contain two types of secretory granules, referred to as type 1 and type 2 granules. Type 1 granules are electron dense granules that contain an electron dense matrix. On the other hand, type 2 granules are electron light granules that display a homogenous appearance. Type 1 granules predominate in the secretory cells in the ampulla, whilst type 2 granules predominate in the secretory granules in the isthmus. It has been observed that the number of secretory granules in the ampulla and isthmus increases in the follicular period (1).

Although secretory granules exist in the fimbria and ampulla during all stages of the oestrous cycle, it has been reported that the greatest number of granules is observed in the oestrus phase. It has been ascertained that, in pigs, the rate of protein synthesis in the epithelial cells of the ampulla is greater than that in the isthmus. It has been reported that the alterations that occur particularly during the prooestrus and oestrus phases bear great significance for the capacitation of the spermatozoon and the development of the oocyte (10).

Nitric oxide (NO), which is involved in several metabolic processes and is referred to as the "messenger molecule", is synthesized by nitric oxide synthase (NOS). The NOS enzyme has three different isoforms, namely, the neuronal (nNOS), endothelial (eNOS) and immunological forms. Furthermore, NO plays an important role in the physiology of the reproductive system. It has been indicated that NO plays a regulatory role in multiple processes, including the secretion of gonadotropins, ovulation, regression of the corpus luteum, and early embryonic development. Furthermore, it has been stated that NO produced by blood vessel endothelium and oviduct epithelium has a regulatory role in the production of the oviduct fluid (8).

Apart from the many genomic and metabolic similarities between human and pig, the very high level of compatibility observed between the cardiovascular systems of the two species has resulted in the use of pigs as an optimal model in research on human diseases (8). The present study was aimed at the light and electron microscopic examination of the epithelium of the porcine oviduct, the determination of the histochemical structure of the mucus content of the oviduct, and the demonstration of the localisation and distribution of eNOS activity in the porcine oviduct.

\section{Materials and Methods}

Following the receipt of the approval of the Ethics Board (Decision of the Local Ethics Board for Animal Experiments dated 20.10.2010 and numbered 2010-100365), 5 healthy adult sows were obtained from the Practice and Research Farm of Ankara University, Faculty of Veterinary Medicine. The animals were monitored to determine the particular phase of the oestrous cycle they were in. The sows were euthanized by an intravenous injection of a high dose of anaesthetic. At necropsy, the ovaries of the sows were examined macroscopically. Samples were taken from the fimbria, ampulla and isthmus regions of the oviduct for light and electron microscopic examinations.

Tissue samples taken for light microscopic examination were fixed in $10 \%$ buffered formol solution, washed, passed through a graded series of alcohols, and series of methyl benzoate and benzol before embedded in paraplast. Six-micron-thick sections cut from the tissue blocks were subjected to Mallory's triple staining method modified by Crossmon for general histologic examination (5), the PAS reaction for the demonstration of the presence of neutral mucosubstance (5), and the Alcian blue $\mathrm{pH} 2.5$ method for the demonstration of the presence of acidic mucosubstance (3).

For immunohistochemical investigation, the streptavidin-biotin-immunoperoxidase technique (Strept$\mathrm{ABC}$ complex) was applied. Five-micron-thick sections cut from the tissue blocks and placed on polyl-lysinecoated glass slides (Menzel GmbH \& Co. KG, Braunschweig, Germany) were first subjected to deparaffinization and dehydration, and were later washed in phosphate-buffered saline (PBS, $\mathrm{pH}$ 7.4) for 10 minutes. Subsequent to washing in distilled water for 1-2 minutes, the slides were subjected to an antigen retrieval process in citrate buffer in a microwave oven. Later the 
slides were washed in PBS-T $(0.3 \%)$ three times, each time for 5 minutes. For the inhibition of endogenous peroxide, the slides were maintained in $30 \% \mathrm{H}_{2} \mathrm{O}_{2}$ for 20 minutes. After washed in PBS, the slides were left for incubation in $10 \%$ normal goat serum (Ultra V blockLABVISION TR-125-HL) for 10 minutes. Subsequently, the sections were processed with diluted (1/50) primary antibodies (Rabbit anti e-NOS / NOS-III, LABVISION RB9279-P) (at $+4{ }^{\circ} \mathrm{C}$ for 18 hours).

Later, the sections were washed in PBS-T $(0.1 \%)$ three times, each time for 5 minutes, and incubated with biotinylated secondary antibodies (LABVISION TR125-HL) for 30 minutes at room temperature, again washed in PBS-T $(0.1 \%)$ three times, each time for 5 minutes, and processed with enzyme-conjugated streptavidin (Streptavidin-horseradish peroxidase-LABVISION TR125-HL) for 30 minutes. The sections, which were washed in PBS-T $(0.1 \%)$ three times, were left in a 3amino-9-ethylcarbazole (AEC) chromogen solution (AEC LABVISION TA-125-HA) for 2-3 minutes in order to image the antigen-antibody reaction (the colour reaction was observed under a microscope). After washed in distilled water, the sections were applied Gill's hematoxylin for 20-25 seconds for nuclear staining. In negative control stainings, primary antibodies were replaced by normal goat serum. The subjective evaluation of the immunohistochemical staining was made under a light microscope (Leica DM 2500).

The tissue samples taken for electron microscopic examination were prefixed in glutaraldehydeparaformaldehyde ( $\mathrm{pH}$ 7.4) for 24 hours in accordance with Karnovsky's method (12); were washed in cacodylate buffer for 3 hours, and fixed for a second time in $1 \%$ osmic acid for 2 hours. Subsequently, the sections were left in $0.5 \%$ uranyl acetate for 2 hours, passed through a graded series of alcohols and propylene oxide, and blocked in araldite M. Sections cut from these blocks at a thickness of 300-400 Angström were contrasted as described by Veneable and Coggeshall (25), and were examined under a Carl Zeiss EM 9S-2 model transmission electron microscope.

\section{Results}

The epithelium of the porcine oviduct, similar to the oviduct epithelium of the majority of mammalian species, is composed of a single layer of prismatic epithelium. It was observed that, the number of ciliated cells decreased towards the isthmus, whilst the number of secretory cells increased. The findings obtained in the present study suggested that the height, amount of secretion and ciliary activity of the cells were closely related to the particular phase of the sexual cycle the animal was in. Observations showed that, while the number of cilia and the height of the cells were rather great in the oestrus phase (Figure 1A), the luteal phase was characterized by disruption of cellular integrity, and marked decrease in the number of cilia and amount of cellular secretion (Figure 1B ).

The PAS reaction applied showed that the amount of neutral mucosubstance increased markedly in the oestrus period and that this secretion was abundant particularly in the crypts. It was observed that the amount

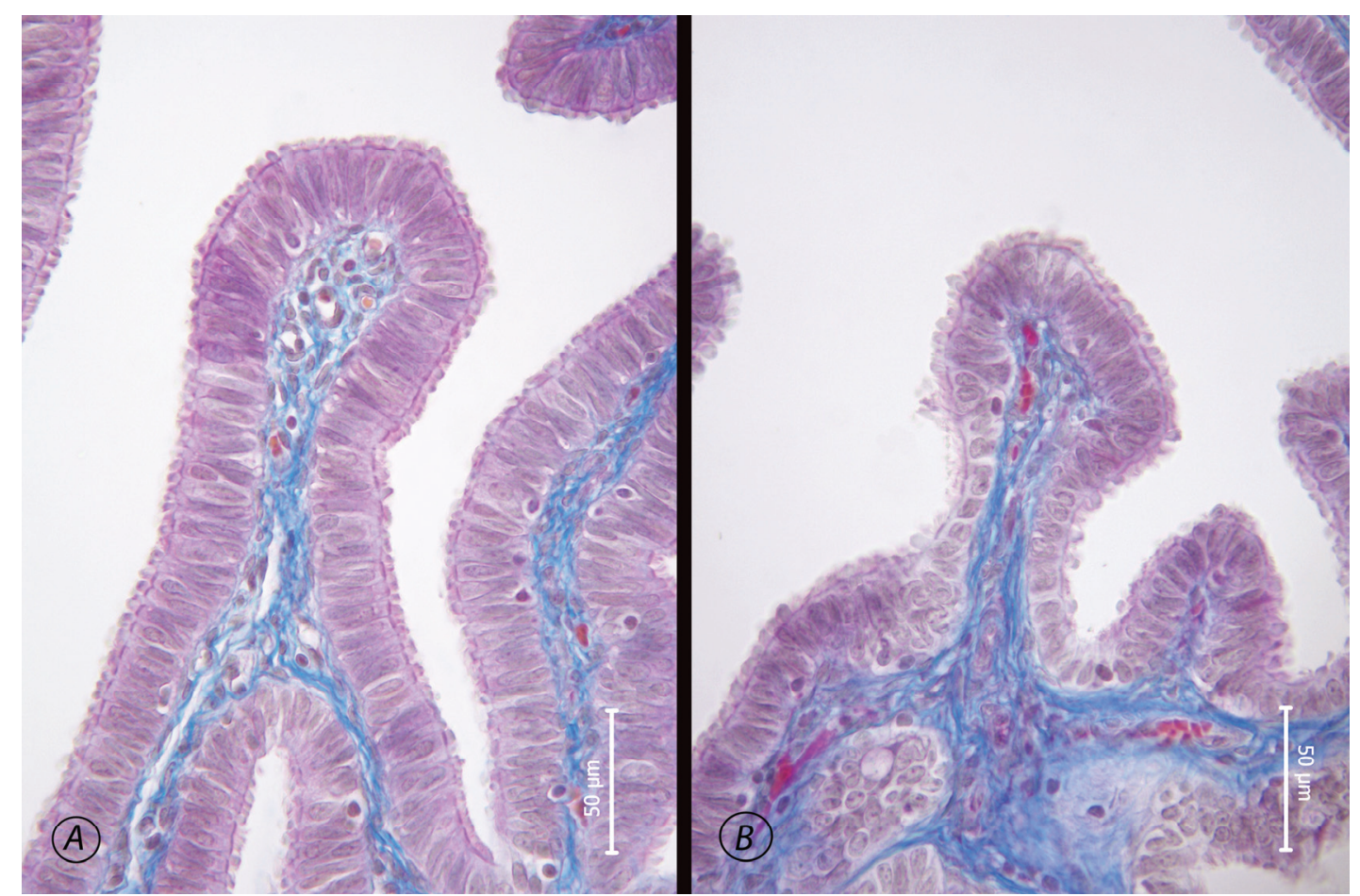

Figure 1. Epithelium of the porcine oviduct, Mallory's trichrome. A. Epithelium of ampulla during the oestrus phase. B. Epithelium of ampulla during the luteal phase.

Şekil 1. Domuz ovidukt epiteli, Mallory’nin üçlü boyaması. A. Östral dönemde ampulla epiteli. B. Luteal dönemde ampulla epiteli. 
of the neutral mucosubstance increased towards the isthmus and that this increase was most evident in the crypts in the oestrus phase (Figure 2). The alcian blue $\mathrm{pH}$ 2.5 staining technique demonstrated that the amount of acidic mucosubstance was rather limited.

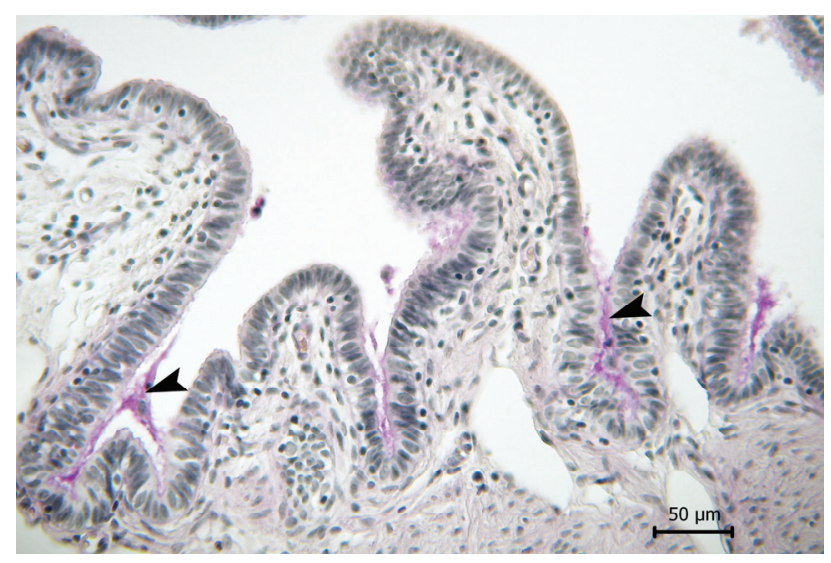

Figure 2. Epithelium of ampulla in the porcine, oestrus phase, PAS reaction (arrow head).

Şekil 2. Domuzda ampulla epiteli, östral dönem, PAS reaksiyonu (ok başı).

During both phases, eNOS expression was observed neither in the ampulla nor in the fimbria. On the other hand, eNOS expression in the epithelial cells of the isthmus region (Figure 3E, arrowhead) and the endothelium of the serosal blood vessels produced strong positive reaction in the oestrus phase (Figure 3, asterisk), whilst in the luteal phase, eNOS expression produced a negative reaction in the epithelium and a rather weak positive reaction in the endothelium of blood vessels (Figure 3, asterisk). The eNOS reactions observed in the blood vessel walls in this region were stronger in the oestrus phase. Throughout the sexual cycle, eNOS activity was not observed in smooth muscle cells in any of the oviduct regions. The reaction in the veins (Figure $3 \mathrm{~A}$, arrows) was weaker in comparison to the reaction in the arteries (Figure 3A, arrowheads). No reaction was observed in the lymph vessels (Figure 3D, arrows).

Electron microscopic findings revealed that the lamina epithelialis of the fimbria was composed of ciliated and secretory cells (Figure 4). Kinocilia were situated in the apical region of ciliated cells, whilst glucose particles were found basally to the kinocilia. Depending on the phase of the sexual cycle, it was observed that the secretion produced by secretory cells was released from the apical region of the cells. It was observed that secretory cells contained electron light and electron dense secretory granules (Figure 5). The increased number of secretory granules was also evident in electronic microscopic examinations. In addition to secretory and ciliated cells, basally to the lamina epithelialis, cells, which were poor in organelles and bore cytoplasmic extensions, were situated along the basal membrane (Figure 6).

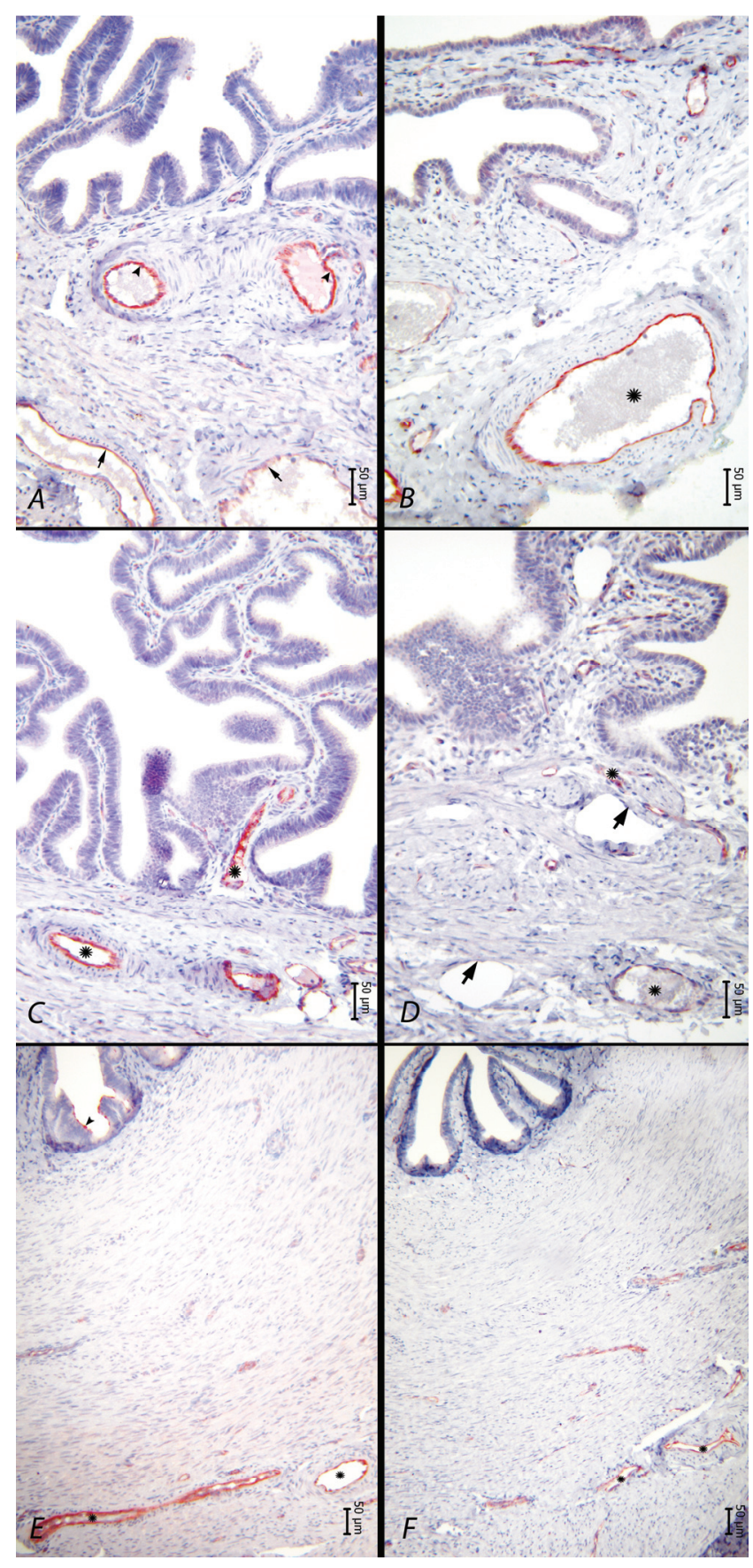

Figure 3. NOS reaction. A. epithelium of fimbria, oestrus phase. Endothelium of blood vessels in lamina propria (arrow heads), endothelium of blood vessels in submucosa (arrows). B. Epithelium of fimbria, luteal phase, blood vessels showing NOS positive reaction in submucosa (asterix). C. Epithelium of ampulla. Oestral phase. Blood vessel showing NOS positive reaction (asterix). D. Epithelium of ampulla. Luteal phase. E. Epithelium of isthmus, oestral phase. F. Epithelium of istmus, luteal phase.

Şekil 3. NOS reaksiyonu. A. Fimbriya epiteli, östral dönem, lamina propriyadaki damarların endoteli (ok başları), submukozadaki damarların endoteli (oklar).

B. Fimbriya epiteli, luteal dönem, submukozada NOS pozitif reaksiyon veren damar (asterisk). C. Ampulla epiteli, östral dönem, NOS pozitif reaksiyon veren damar (asterisk). D. Ampulla epiteli, luteal dönem. E. İstmus epiteli, östral dönem. F. İstmus epiteli, luteal dönem. 


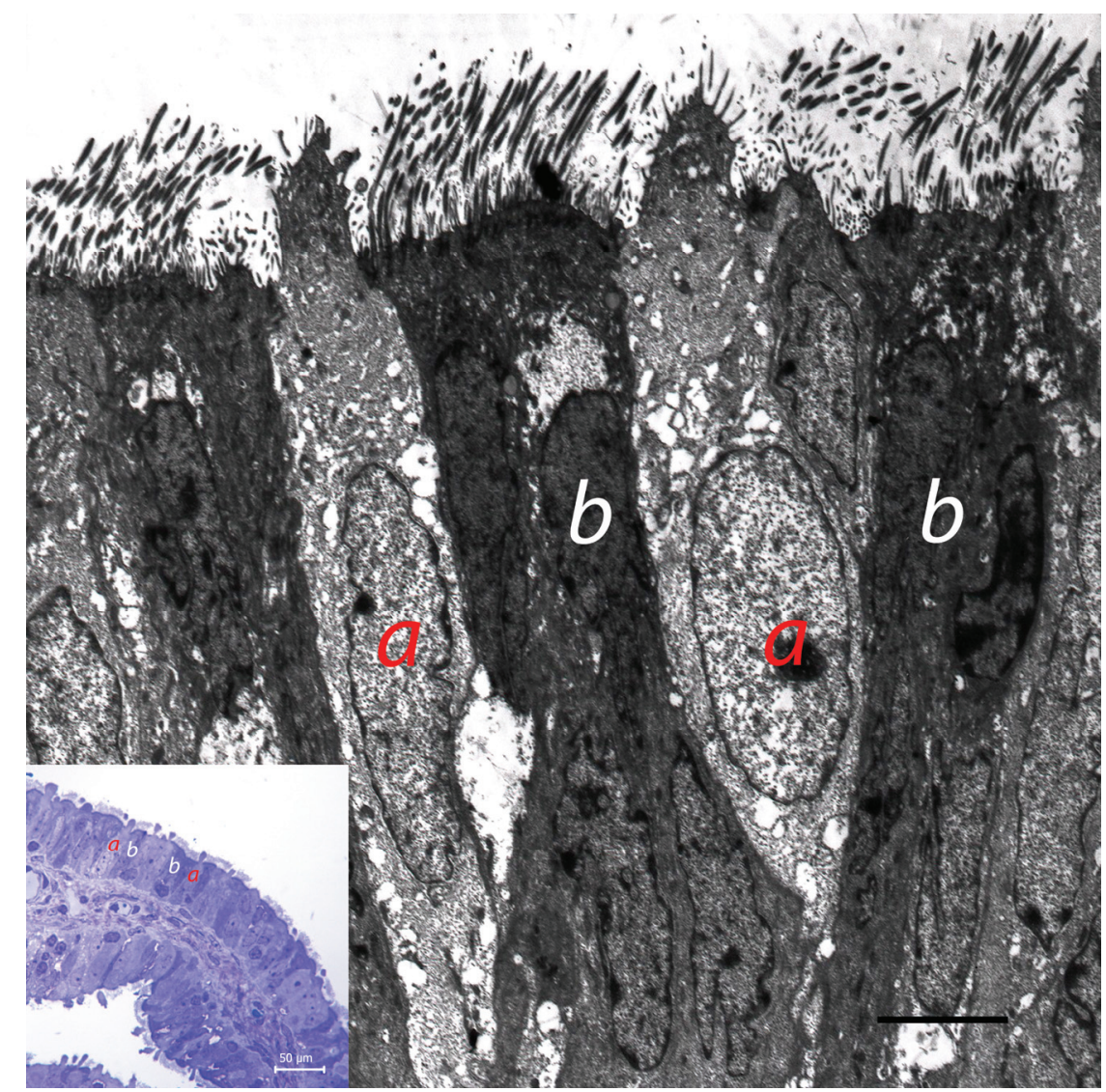

Figure 4. Electron microscopic appearance of epithelium of fimbria secretory cell (a), ciliated cells (b), secretory and ciliated cells in semi-thine section (small photo).

Şekil 4. Fimbriya epitelinin elektron mikroskobik görünümü. Sekretorik hücre (a), silyumlu hücre (b), yarı ince kesitte silyumlu ve sekretorik hücreler (küçük fotoğraf).

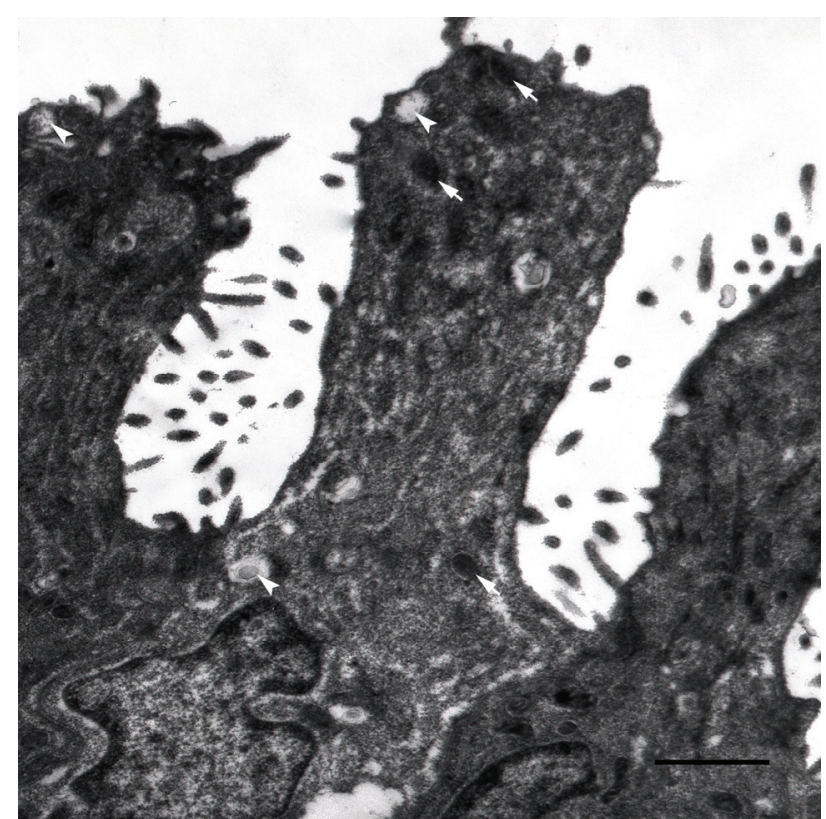

Figure 5. Secretory granule types in secretory cells in epithelium of fimbria. Electron light granules (arrow head), electron dense granules (arrows) x13500

Şekil 5. Fimbriya epitelinde sekretorik hücrelerde salg1 granülü tipleri. Elektron açık granüller (ok başı), elektron koyu granüller (oklar). x13500.

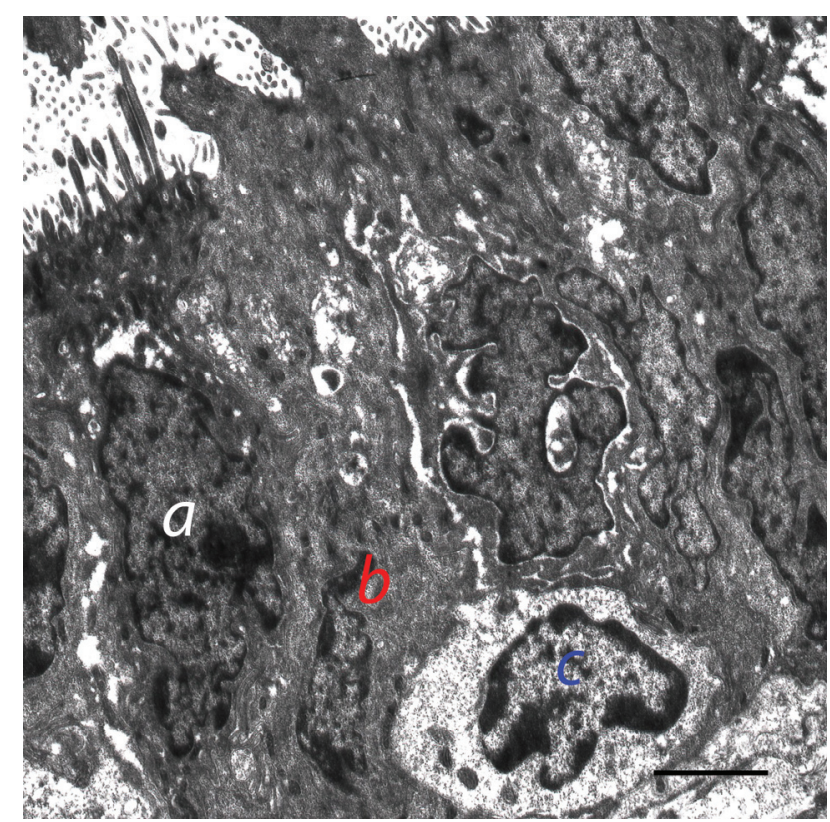

Figure 6. Basal cell in the epithelium of sow oviduct. $\mathrm{x} 4500$. Ciliated cell (a), secretory cell (b), basal cell (c). x4500.

Şekil 6. Domuz ovidukt epitelinde bazal hücre. Silyumlu hücre (a), sekretorik hücre (b), bazal hücre (c). x4500. 


\section{Discussion and Conclusion}

The mammalian oviduct, which is composed of two types of cells, namely, ciliated and secretory cells, creates a special environment for the maturation of the oocyte, capacitation of the spermatozoon, fertilization, and the early phases of embryonic development $(1,7,11)$. These two types of cells can be easily differentiated in pigs, based on the differences observed in the cytoplasmic concentration of the cells, the secretory granules found on the apical surface of the cells, and the presence or lack of cilia. It has been reported that, apart from these cells, particularly in the basal region of the epithelium, globular, lymphocyte- and monocyte-like cells with cytoplasmic extensions and heterochromatic nuclei were found $(1,4,14,15,16)$. The investigation of the proportion of ciliated and secretory cells revealed that the number of ciliated cells in the fimbria was very high and the numbers of both types of cells were equal in the ampulla, whilst the number of secretory cells was much greater in the isthmus (11). In the present study, in compliance with previous reports, it was observed that, apart from ciliated and secretory cells, basal cells were situated along the basal membrane.

It has been indicated that the ultrastructural features of ciliated and secretory cells altered markedly during the oestrus and luteal phases (1). Throughout the oestrous cycle, while numerous secretory granules are observed in secretory cells particularly located in the isthmus, the number of secretory granules decreases markedly in the luteal phase. While the number of cilia decreases markedly in the fimbria and ampulla regions in the luteal phase, the number of cilia in these regions increases during the oestrus phase $(1,2)$. Another pronounced alteration observed during the oestrus phase was the progressive increase of the amount of secretion found within the crypts towards the isthmus. This increase is considered as evidence of the isthmus serving as a reservoir of spermatozoa in sows.

In a study conducted by Johansson et al. (11), the GAGs found in the porcine oviduct were identified by immunohistochemical methods. Researchers (11,21,23, 24) determined that, spermatozoa located in the uterotubal junction and isthmus in cows, are located in the deeply situated narrow oviduct crypts in sows.

In the present study, it was also observed that, the amount of GAGs in the crypts increased towards the isthmus. The neutral mucosubstance being the dominant component of the content of the crypts in the oestrus phase was in support of the findings of the above mentioned research. The authors consider that, the increased GAG secretion of the crypts in the oestrus phase enables spermatozoa to acquire motility and fertilization capability.

Abe and Hoshi (2) have reported that two types of secretion granules were differentiated in secretory cells in the pig, namely, electron dense and electron light granules. Literature reports indicate that electron dense granules predominate in the ampulla, whilst electron light granules predominate in the isthmus. Similarly, in the present study, electron dense and electron light granules were observed in secretory cells. While the findings obtained in the present study are in agreement with findings obtained in previous research for the types of granules observed in secretory cells, it was also determined that the same type of granules were found in the secretory cells of the different regions of the porcine oviduct. The secretory cells of the ampulla and isthmus regions did not differ from each other for the type of secretory granules they contained. Furthermore, the findings of the present study were in agreement with those obtained in previous research, in that the number of secretory granules found in secretory cells increased in the oestrus phase.

NO, produced by the endothelium of blood vessels and the oviduct epithelium, plays an important role in reproductive physiology. It has been reported that NO has a regulatory role in several processes, including ovulation, regression of the corpus luteum, and early embryonic development (8). In the present study, while eNOS expression was not observed in the epithelium of either the ampulla or the fimbria during both the oestrus and luteal phases, in the oestrus phase, strong eNOS expression was determined in both the epithelial and endothelial cells of the isthmus.

In result, in light microscopic examinations performed in the present study, during the oestrus phase, increased secretion by the crypts was demonstrated by means of the PAS reaction, and it was observed that secretion increased progressively towards the isthmus. Furthermore, electron microscopic examinations revealed that this secretion contained two different types of secretory granules, namely, electron light and electron dense granules.

\section{References}

1. Abe H, Hoshi H (2007): Regional and cyclic variations in the ultrastructural features of secretory cells in the oviductal epithelium of the Chinese Meishan pig. Reprod Dom Anim, 42, 292-298.

2. Abe H, Hoshi H (2008): Morphometric and ultrastructural changes in ciliated cells of the oviductal epithelium in prolific Chinese Meishan and large white pigs during the oestrous cycle. Reprod Dom Anim, 43,66-73.

3. Bancroft J D, Gamble M (2002): Histological Techniques. 5th edition, London, Philadelphia: Churchill \& Livingstone, pp.182-189.

4. Bullon F, Merchan J A, Gonzalez-Gomez F, Furio V, Poblete EG (1980): Ultrastructure of the oviductal mucosa of the rat. III. Basal and Peg cells. Int J Fertil, 25, 293297. 
5. Culling C F A, Allıson R T, Barr WT(1985) : Cellular Pathology Technique. Fourth edition, Butterworth, Wellington.

6. Dziuk P(1991): Reproduction in the pig. 471-487. In: Reproduction in Domestic Animals. Academic press inc.

7. Gawronska B, Stepien A, Ziecik AJ (2000): Role of luteinizing hormone in control of oviduct function. Reprod Dom Anim, 35, 129-133.

8. Hao YH, Yong HY, Murphy CN, Wax D, Samuel M, Rieke A, Lai L, Liu Z, Durtschi DC, Welbern VR, Price EM, McAllister RM, Turk JR, Laughlin MH, Prather RS, Rucker EB (2006): Production of endothelial nitric oxide synthase (eNOS) over-expressing piglets. Transgenic Res, 15,739-750.

9. Hunter RHF, Baker TG, Cook B (1982): Morphology, histology and steroid hormones of the gonads in intersex pigs. J Reprod Fert, 64, 217-222.

10. Jiwakanon J, Persson E, Kaeoket K, Dalin A-M (2005): The sow endosalpinx at different stages of the oestrous cycle and at anoestrus: Studies on morphological changes and infiltration by cells of the immune system. Reprod Dom Anim, 40, 28-39.

11. Johansson $\mathbf{M}$, Tienthai $\mathbf{P}$, Rodriguez-Martinez $\mathbf{H}$ (2000): Histochemistry and ultrastructure of the intraluminal mucus in the sperm reservoir of the pig oviduct. J Reprod Dev, 46,183-192.

12. Karnovsky M J (1965): A formaldehyde-glutaraldehyde fixative of high osmolality for use in electron microscopy, J Cell Biol, 27, 137A-138A.

13. Kouba AJ, Abeydeera RL, Alvarez IM, Day BN, Buhi WC (2000): Effects of the porcine oviduct-specific glycoprotein on fertilization, polyspermy and embryologic development in vitro. Biol Reprod, 63,242-250.

14. Odor DL (1974): The question of 'basal' cells in oviductal and endocervical epithelium. Fertil Steril, 25, 1047- 1062.

15. Özen A, Ergün E, Kürüm A (2010): Histomorphology of the oviduct epithelium in the Angora rabbit. Tr J Vet Anim Sci, 34(3), 219-226.

16. Paurstein C J, Woodruff J D (1967): The role of the 'indifferent' cell of the tubal epithelium. Am J Obstet Gynecol, 98, 121.
17. Rodriguez-Martinez H (2007): Role of the oviduct in sperm capacitation. Theriogenology, 68,138-146.

18. Shilling E (1974): Stages of ovarian function in the sow. Vet Med Rev,1,59-64.

19. Stalheim OHV, Gallagher JE, Deyoe BL (1975): Scanning electron microscopy of the bovine, equine, porcine and caprine uterine tube (oviduct). Am J Vet Res, 36, 1069-1075.

20. Steffl M, Schweiger M, Amselgruber WM (2005): Estrous cycle specific immunolocalization of different domains of the epidermal growth factor receptor in the porcine oviduct. Endocrine, 27, 289-294.

21. Szulanczyk K (2009): Histological changes within ovarian cortex, oviductal and uterine mucosa in case of ovarian cysts presence in sows. Folia Histochem Cytobiol, 47, 99103.

22. Tienthai P, Suzuki K, Pertoft H, Kjellen L, RodriguezMartinez H (2000): Production of glycosaminoglycans by the porcine oviduct in relation to sperm storage. Reprod Dom Anim, 35, 167-170.

23. Tienthai P, Yokoo M, Kimura N, Heldin P,Sato E, Rodriguez-Martinez H (2003): Immunohistochemical localization and expression of the hyaluronan receptor CD44 in the epithelium of the pig oviduct during oestrus. Reproduction, 125,119-132.

24. Töpfer-Petersen E (1999): Carbohydrate-based interactions on the route of a spermatozoon to fertilization. Human Reproduction Update, 5, 314-329.

25. Veneable J H, Coggeshall R. (1965): A simplified lead citrate stain for use in electron microscopy. J Cell Biol, 25, 407- 408.

Geliş tarihi: 28.03.2012 / Kabul tarihi: 29.05.2012

\author{
Address for correspondence: \\ Asuman Özen \\ Department of Histology and Embryology, \\ Faculty of Veterinary Medicine, \\ University of Ankara \\ 06110 Dışkapl, Ankara-TURKEY \\ e-mail: Ozen@veterinary.ankara.edu.tr
}

